\section{The digitalization in EMAS- registered organizations: evidences from Italy and Poland}

Digitalization in EMASregistered organizations

Rossella Canestrino

Department of Management and Quantitative Studies, University of Naples - Parthenope, Napoli, Italy

Marek Ćwiklicki

Department of Public Management, Cracow University of Economics, Krakow, Poland

Piotr Kafel

Department of Quality Management, Cracow University of Economics, Krakow, Poland

Magdalena Wojnarowska

Department of Technology and Ecology of Products, Cracow University of Economics, Krakow, Poland, and

Pierpaolo Magliocca

Department of Economics, University of Foggia, Foggia, Italy
Received 28 December 2019 Revised 8 March 2020 Accepted 14 March 2020

\section{Abstract}

Purpose - The aim of this paper is to investigate the scope of digitalization in the EMAS-registered organizations for better understanding its extent in environmental committed firms' activities.

Design/methodology/approach - A content analysis was employed to examine the environmental statements of the EMAS-registered organizations. About 60 Italian and Polish entities were selected from the EMAS database using simple random sampling method.

Findings - The article fills the gap in the theory of managing change in an environmental context, suggesting that the action plan for sustainable development does not meet the objectives of digitalization. Organizations registered in EMAS do not express a strong tendency to introduce ICT in the pursuit of environmental goals, which is contrary to the assumptions about the benefits of digitalization for sustainable development.

Research limitations/implications - The first limitation refers to the small size of the sample. Since environmental statements are always published in national languages, only two countries - Italy and Poland were chosen for investigation. The use of national language hinders comparison, but the inclusion of more registered organizations could give additional explanations. Secondly, the content analysis would have benefited from the collection of additional source of information (webpages and company documentations), since many firms do not refer to digitalization in the environmental statements. Gathering primary data from managers explaining the motives behind their strategic environmental decisions could be also useful.

Practical implications - Giving the agreement about the environmental advantages of digitalization, this study offers to the practitioners the chance to catch new opportunities within the field of environmental sustainability by the employment of more integrated approach to digitalization.

(C) Rossella Canestrino, Marek Ćwiklicki, Piotr Kafel, Magdalena Wojnarowska and Pierpaolo Magliocca. Published by Emerald Publishing Limited. This article is published under the Creative Commons Attribution (CC BY 4.0) licence. Anyone may reproduce, distribute, translate and create derivative works of this article (for both commercial and non-commercial purposes), subject to full attribution to the original publication and authors. The full terms of this licence may be seen at http://creativecommons.org/ licences/by/4.0/legalcode

The Project has been financed by the Ministry of Science and Higher Education of Poland within "Regional Initiative of Excellence" Programme for 2019-2022. Project no.: 021/RID/2018/19. Total financing: 11897 131,40 PLN. 
TQM

32,4

674

Originality/value - To the best of the authors' knowledge, this is the first study to examine two dynamically developing areas, namely digitalization and environmental sustainability. This study enriches current knowledge about both areas, examining the level of digitalization of European high-environmental performing firms. In doing this, it reports lack of important use of digitalization in the action plans for environmental commitments in Polish and Italian EMAS-registered organizations.

Keywords Environmental commitment, EMAS, Digitalization, ISO 14001, Sustainability

Paper type Research paper

\section{Introduction}

One of the most attractive goals for the contemporary firms is digitalization described as any change in the organization and its business model due to the increasing use of electronics and telecommunication technologies (Verina and Titko, 2019; Unruh and Kiron, 2017; Westerman et al., 2011). Digitalization is supported by new information and communication technologies (ICTs) (Kobus et al., 2018) embracing systems such as virtualization mobility and analytical systems (Loonam et al., 2018), promising to revolutionize the way business is conducted within industrial value chains through the use of Internet of things (IoT), technologies, intensive data exchange and predictive analytics (Rachinger et al., 2019; Wade, 2015). Using digital technologies provides new business opportunities, supporting value-producing opportunities, revenue growth and operating efficiency (Gimpel and Schmied, 2019; Coupette, 2015; Kagermann, 2015; Kaufmann, 2015; Loebbecke and Picot, 2015). The mentioned opportunities motivate many firms to experiment with innovative business models based on digital technology (Baines et al., 2017), even if, despite the often substantial investments companies have made in digital initiatives, few were able to experience the expected growth (Desmet et al., 2015). Thus, there is a high level of variance in the integration of digital technologies and progress toward the digital economy within the European countries (Evangelista et al., 2014; Kyriakidou et al., 2011; Scholz et al., 2018).

The use of digital technologies, considered as a core part of Industry 4.0, is no more an optional choice to manufacturers; it is rather an imperative for survival. Standard \& Poor's data show that digitization is placing unprecedented pressure on organizations to evolve. At the present rate, $75 \%$ of S\&P 500 incumbents will be gone by 2027 (Capozzi et al., 2014). That means managing firms' transition to a digitally driven business model is not just critical to beating competitors; it is crucial to company's viability.

Parallel to the development of digitalization, environmental problems are changing firms' business models. Over the past few decades, more and more companies have started to use solutions that combine competitive success with the protection of natural resources (Pane-Haden et al., 2009; Klute-Wenig and Refflinghaus, 2015; Jabbour et al., 2015). Accordingly, ISO 14001 and EMAS (Eco-Management and Audit Scheme) requirements were introduced. Those two are the most recognized initiatives that enable companies to implement an environmental management system (EMS) to improve their environmental performance (Daddi et al., 2014; Chiarini, 2013). These management systems are usually implemented and integrated with other management systems described in ISO 9001, ISO 45001, ISO 26000 or ISO 50001 standards (Kafel and Casadesus, 2016).

Digitalization of industry provides a wide range of opportunities for the improvement of environmental performance, as well as for economic and social dimensions of sustainability (Parida et al., 2019; Ringenson et al., 2018). Environmental goals may be achieved through smart manufacturing reducing the environmental footprint compared to conventional manufacturing processes. For example, monitoring operational data allows to reduce scrap rates and equipment wear and tear (Sjödin et al., 2018). Nevertheless, there is very little research addressing the impacts of digitalization on environmental aspects of sustainability and sustainable development (Beier et al., 2017). The literature is still nascent in these domains, and research gaps remain in analyzing how industrial companies 
leverage digitalization to transform their business models to achieve sustainability benefits (Parida et al., 2019). To the best of the authors' knowledge, this is the first paper attempting to merge the concepts of digitalization and environmental issues. Particularly, the ItalianPolish research team examined the scope of digitalization in a selected sample of EMASregistered organizations, because this regulation is the most recognized among European firms committed to improve their environmental performance (Testa et al., 2014; Morrow and Rondinelli, 2002). The research objective is to identify and analyze the extent to which environmental committed firms exploit the opportunities provided by digitalization to reach their environmental goals. In doing this, two research questions were answered:

(1) What kinds of digitalization are employed by EMAS-registered organizations?

(2) Does digitalization in these organizations change due to time?

The paper is organized in five sections: first, it opens with a literature review aimed at providing a sufficiently exhaustive conceptual representation of the existing linkage between environmental issues and digitalization; then the methodology is detailed; next the results of the analysis are described and the implications discussed under both theoretical and practical profiles. The conclusions of the paper are presented along with the limitations of the study and ideas for a future research agenda.

\section{Literature review: digitalization and environmental protection}

\subsection{The environmental impacts of digitalization}

Over the past few decades, more and more companies have started to use solutions that combine business success with the protection of natural resources (Pane-Haden et al., 2009). Such initiatives are fostered by global recession problems, as well as by uncertain competitive environments, which turned into the need to reduce costs (Fokina et al., 2018). Environmental changes result in the implementation of alternative business solutions expected to bring specific environmental benefits (Van der Leeuw, 2018). Among them, digitalization, considered as the way to transform a current way of doing things into an electronic form by using new technologies (Warner and Wäger, 2019), directly impacts not only on firm's economic performance (Parida et al., 2014) but also on its environmental one (Parida et al., 2019).

Most of the literature dealing with the environmental impacts of digitalization is examined in the field of sustainability, sustainable development (Parida et al., 2019; Ringenson et al., 2018; Heiskala et al., 2016) and circular economy (CE) (Bressanelli et al., 2018; Oghazi and Mostaghel, 2018).

Creating a sustainable industry depends on targeting the economic, sustainable and social benefits over the long term (Canestrino et al., 2016; Barbier, 1987). Many companies are working according to this holistic perspective; handling digitalization is the essential driver of sustainability. Beier et al. (2017) summarize existing research findings addressing the impact of digitalization on industry-relevant sustainability aspects, underlining a substantial lack of contributions about the linkage between the digitalized industry and the potentials for resource efficiency and renewable energy. By contrast, the available studies are mainly focused on changes in industrial work life, as well as on business models as the key factor in enabling sustainable industry through digitalization, as the literature on business models for digitalization was exponentially expanding during the last three years (Parida et al., 2019). The authors discuss the changes that digitalization is expected to bring about in the industrial sector by comparing a highly industrialized economy (Germany) with a major emerging industrial market (China). According to research's results, digital transformation affects both the ecological (resource efficiency, renewable energy) and the social dimensions of sustainability, shaping the sustainable development of countries with a largely different structure in their manufacturing sector (Beier et al., 2017). Moreover, better living conditions, active public participation, dynamic urban

\section{Digitalization in EMAS- registered organizations}

675 
TQM

32,4

framework, clean governance and transparency in public welfare policies and procedures are observed as potential benefits of digitalization (Bhutani and Paliwal, 2015; Seele and Lock, 2017).

Discussing digitalization within sustainability requires mentioning about relations with $\mathrm{CE}$ as a widely recognized concept for business model transition toward environmental protection. Digitalization is perceived as an enabler of CE (Antikainen et al., 2018). The explanation behind this statement is simple: the digitalization allows to "close the loop, slow the material loop and narrow the loop with increased resource efficiency" (Antikainen et al., 2018). Expected to transform production as more environmental friendly, it also improves information sharing in society and along a value chain and empowers consumers (Hedberg et al., 2019). A study on the relationship between sustainable production tools and $\mathrm{CE}$ shows that the highest level of integration with $\mathrm{CE}$ exists between EMS and eco-design (Marrucci et al., 2019).

It's a matter of fact that ICT and digitalization increase firm's process efficiency through continuous analysis of operational data and the identification of process-performance bottlenecks (Cenamor et al., 2017). As Sjödin et al. (2018) noted, process efficiency also benefits from self-correcting systems that reduce repair-time averages and optimize capacity. Moreover, a cost-efficient resource utilization is gained through monitoring and process optimization, while analytics facilitate the identification of the root causes of defects, leading to a reduction in both the scrap rates and the lead times (Grubic and Jennions, 2018; Porter and Heppelmann, 2015). Optimizing resource efficiency in production companies supports energy saving and also contains the potential to increase the share of renewable energy consumed in industrial production (Beier et al., 2017). Not surprising, digitalization is claimed as a way to reduce the environmental impact of production and to directly and indirectly benefit the society through incremental improvements in efficiency and radical organizational methods (Bieser and Hilty, 2018; Gorissen et al., 2016).

Over the past ten years, a general consensus has emerged that digitalization and ICT support the development of more environmental-friendly strategies and actions by:

(1) Decreasing the negative impacts (in terms of pollution) of production, distribution, operation and disposal through improved energy and materials efficiency, increased use of renewable energy sources, improved recycling and end-of-life disposal of ICTs.

(2) Increasing the enabling effects of ICTs and digitalization on the development of a green economy.

(3) Supporting systemic effects that result in the transformation of behavior, attitudes and values of individuals as citizens and consumers; economic and social structures; and governance processes (Ciocoiu, 2011).

As already noted, improving resource efficiency and increasing the use of renewable energy sources are mentioned as the main environmental benefits coming from digitalization (Parida et al., 2019; Bieser and Hilty, 2018; Gorissen et al., 2016; Rohn et al., 2014). The largest influence of digitalization is likely to be in enabling energy efficiencies in other sectors. Energy savings are possible through better monitoring and management of electricity grids (Webb, 2008) and the reduction of greenhouse gas (GHG) emissions. According to Bieser and Hilty (2018), digitalization supports the reduction of GHG emissions enabling people to work from home and have virtual meetings, thus avoiding travel-related emissions (indirect effects). By contrast, digitalization causes a growth in toxic emissions (e.g. pollution and energy to manufacture and for disposal, etc.) because increasing amount of ICT hardware is produced, powered with electricity while being used and finally disposed (direct effects) (Forge et al., 
2009; Bieser and Hilty, 2018). The infrastructure supporting digital processes usually requires the use of scarce and rare earth metals, thus considering that the depletion of natural resources should be taken into account as a negative environmental impact of digitalization (Scholz et al., 2018). This is closely related to recyclability and e-waste issues. If not done right, processing e-waste can lead to adverse health effects and environmental pollution (AksinSivrikaya and Bhattacharya, 2017). The carbon footprint of the ICT sector must be reduced, and according to Hilty and Bieser (2017), it is technologically and economically feasible due to efficiency gains.

Even if the negative direct effects of digitalization are pointed by the researchers (Scholz et al., 2018; Gimpel and Schmied, 2019; Forge et al., 2009), most of the available studies conclude that indirect effects are desirable for environmental protection (e.g. reducing GHG emissions) and clearly larger than direct effects (e.g. leading to a significant total reduction of GHG emissions) (Bieser and Hilty, 2018; GeSI, 2015; Pamlin and Szomolányi, 2006). As the Global e-Sustainability Initiative (GeSI) (2015) reports, the ICT applications could avoid up to $20 \%$ of annual GHG emissions in 2030 (indirect effect), while causing about $2 \%$ of global GHG emissions (direct effect).

\subsection{Firms' environmental commitment: the EMAS certification}

The transition to the new economic model requires entrepreneurs to change their management approach. EMSs are a way in which companies can internalize environmental problems (Steurer et al., 2005), demonstrating a proactive approach to sustainable development (Berry and Rondinelli, 1998). It means that the main goal of EMS is to improve firms' environmental performance. Accordingly, attaining an environmental certification represents a relevant achievement for an organization, since it demonstrates firm's commitment to environmental sustainable production processes. To date, the main international reference standards for EMS are ISO 14001 certification, which gave all companies around the world the opportunity to implement certified third-party EMS, and the European EMAS regulation (Morrow and Rondinelli, 2002; Testa et al., 2014; ISO 14001:2015, 2015). ISO 14001 and EMAS enable companies to implement a formal EMS (Hillary, 1999). Although both systems have the same overall goal of reducing the organization's environmental impact, there are significant differences between them (Freimann and Walther, 2002). Daddi et al. (2014) examined the impact of ISO 14001 and EMAS standards in terms of reducing environmental impact. Both systems have a positive impact on energy-intensive industries. Nevertheless, ISO 14001 is more effective in the short time, while EMAS companies perform better in the long time (Daddi et al., 2014). ISO 14001 is mainly motivated by external factors such as business and industry associations or customer pressure. EMAS is more internally driven and is recognized as a premium standard in environmental management. According to Neugebauer (2012), the motivations for implementing EMS are very different with respect to EMAS or ISO 14001. While ISO 14001 is often a response to external pressure, EMAS is significantly linked to the internal environment (Neugebauer, 2012).

EMAS is perceived as the highest ecological distinction for enterprises and noncommercial institutions (Preziosi et al., 2016). The registered organizations include leaders of environmental changes in their sectors at the regional, national and even global level. These organizations are the authors of the best solutions in the field of environmental protection and eco-innovation. In their industries, these companies are the benchmark for assessing environmental performance. In addition, EMAS differs from other environmental management systems, among others, the obligation to carry out an initial environmental review, periodically publish environmental statements and the possibility of using an identifiable logo (Iraldo et al., 2009).

\section{Digitalization in EMAS- registered organizations}


TQM

32,4

According to the aforementioned, EMAS is considered the most credible and robust environmental management tool, adding several elements in addition to the requirements of the international standard EN ISO 14001. The continual improvement of environmental performance of the registered organizations justifies the choice of the research team to adopt EMAS register, coordinated by European Commission (European Commission, 2019), as database for the selection of the research sample. Minimal requirements of environmental reporting for EMAS-registered organizations are defined in Annex IV of the EU Regulation 1221/2009 (EU, 2009). Moreover, organizations that are certified as being complied with EMAS standard are recorded in the EU EMAS Registration database while similar database for ISO 14001 does not exist.

\section{Methodology}

\subsection{Research design}

This study followed an explorative approach. In order to answer the research questions, the research team performed a content analysis of environmental statements issued by organizations coming from two countries - Italy and Poland. Since EMAS statements are published only in national language, Italian and Polish organizations were selected as fitting with the research team countries of origin. As mentioned, the EMAS certifies the implementation of EMS and an environmental awareness in these organizations. Moreover, the EMAS environmental statements are the subject of an external evaluation that diminishes company's subjectivity.

As first step of the research, the key requirements of firms' transition toward digitalization were discussed and defined in order to grasp the extent of firms' commitment in exploiting digitalization to get their environmental goals. Calvino et al. (2018) propose as key indicators for digitalization of business sectors the following ones: a technological component (ICT investment, purchases of ICT intermediates, robot use), a human component (ICT specialists) and online sales. Presented typology of measures for digital transformation of sectors explains the complexity of this area, but the ICT equipment and services are at the core of digitalization. Al-Samawi (2019) introduces the requirements of a digital firm providing its labels as digital, namely digital employee, digital culture, digital communication, fast knowledge of modern technologies, central digital data storage, digital archive, digital library, digital help support, using original software, existence of security policy, digital intelligent decision-making, ergonomic workplace suited for IT tools usage and existence of IT department. Despite existing difficulties in defining digital enterprise, the use of IT tools is represented by:

(1) Managing the entire asset through the digital means;

(2) Making data available anywhere, at any time;

(3) Acting in a flexible way (changing quickly according to business environmental changes);

(4) Working effectively all the time (24/7 work mode) and anywhere (Laudon and Laudon, 2012).

Dealing with firms' digitalization, Matt et al. (2015) identified the four dimensions of digital transformation strategies, independent of the industry or firm, namely the use of technologies, changes in value creation, structural changes and financial aspects. The use of technologies addresses a company's commitment toward new technologies and its ability to exploit them. It often implies changes in value creation. Digitalization allows companies to either revise or extend their portfolio of products and services by incorporating IoT components or even 
combining different offerings with unique opportunities (Cenamor et al., 2017; Hasselblatt et al., 2018). Both the adoption of new technologies and the required changes in value creation impel firms to adjust its organizational structure (Desmet et al., 2015). Such structural changes are often needed to provide an adequate foundation for the new operations: the challenge is moving toward a structure that is agile, flexible and increasingly collaborative while keeping the rest of the business running smoothly (Catlin et al., 2015). As Matt et al. (2015) noted, the former three dimensions can only be transformed under the condition of financial sustainability as "financial aspects are both a driver and a bounding force for the transformation" (p. 215). The evaluation of firm's success in digitalization depends on the ability to measure the achievement of the mentioned requirements. However, Hess et al. (2016) emphasize that these building blocks are too vague to provide a clear guidance on how to structure digital transformation initiatives.

Based on a review and analysis of the existing literature, Parida et al. (2019) clearly show that existing studies about digitalization mainly focus on the way it enables business model innovation. Challenges related to value creation, value delivery and value capture components of business model innovation need further investigation, as well as the way digitalization impacts the relationship among the key players peopling the industrial ecosystem within which firms locate. It means, therefore, that despite their effectiveness, existing models lack in considering the way firms use digitalization to manage the relationships with the market (both input and output markets).

According to I-scoop.eu (2018), "Digitalization means turning interactions, communications, business functions and business models into (more) digital ones which often boils down to a mix of digital and physical as in omnichannel customer service, integrated marketing or smart manufacturing with a mix of autonomous, semi-autonomous, and manual operations." Digitalization overcomes the firm's boundaries, involving the relationships it establishes with the other actors in market. The recent technological developments, such as the mobile revolution, social media or the power of analytics, specifically led to the development of platforms within which business networks and ecosystems are promoted (Rachinger et al., 2019; Barile et al., 2017; Baccarani and Cassia, 2017). In the meantime, customers can access information via the Internet and have multiple channels to choose from (Linz et al., 2017; Berman and Bell, 2011). Thus, externally focused actions appear to be fundamental in the establishment of high-performing digital initiatives. Keen and Williams (2013) and Neumeier et al. (2017) suggest that merely adapting the business model and digital business strategy is not sufficient and that organizations should also improve their capability to flexibly relate to the external environment. Compounding the issue, recent academic work has focused on specific facets of digital transformation rather than providing holistic frameworks of investigation (Gimpel et al., 2018; Hess et al., 2016).

According to the aforementioned, Loonam et al. (2018) model was adopted as framework of investigation, as, to the best of the authors' knowledge, it is among the few and most updated contributions dealing with both internal and external organizational perspectives of digitalization.

\subsection{Research framework}

McKinsey research shows that companies that have successfully transitioned to become high-performing digital enterprises are able to orchestrate six building blocks: strategy and innovation, process automation, organization, technology, data and analytics and the customer decision journey; this last one considered as the firm capacity to understand and skillfully act on complete customer journeys (Fanderl and Perrey, 2014). Similarly, Peter et al. (2020) captured the collective understanding of digital transformation focusing on the need of actors to collaborate around shared understandings of digitalization, both

\section{Digitalization in EMAS- registered organizations}

679 
TQM

32,4

680

internally and externally, to their business organizations. In doing this, customer centricity (in accordance with an external perspective) is identified as belonging to the strategic field of action of digital transformation, aiming at improving the experience of customers through a constant customer orientation, a positive customer experience as well as personalized products and services. Aligning internal perspectives (like business process integration) with external digital technology opportunities leverages significant strategic advantages also for Westerman et al. (2014). Despite the mentioned, holistic contributions about digitalization are still scarce in the literature, as "recent work in academia has been largely concerned with providing guidance on certain aspects of digital transformation" (Hess et al., 2016, p. 124).

Within this lacking field of research, Loonam et al. (2018) proposed a framework to classify the actions required by firms that choose to digitally transform their organizations, and in doing this, they considered both "internal" and "external" organizational perspectives.

Particularly, the authors argue that managerial actions for digitalization may be distinguished in "externally focused" and "internally focused." Both customer-centric actions (designing a customer experience from the outside-in; reaching and engaging customers and online communities; and blending a physical and digital customer experience) and strategycentric actions (creating new digital businesses, reconfiguring value delivery and rethinking value propositions) belong to the external perspective. By contrast, adopting integrated approach to systems across the organization; gaining insights from data analytics; and building across platforms across social and mobile tools (technology) as well as organizational issues (recognize the importance of fostering a digital culture and focus on organizational structures and processes) are considered as "internally focused" action (Loonam et al., 2018).

Figure 1 describes the framework according to which EMAS-registered organizations were considered.

Both external and internal perspectives were used in this research to explore the digitalization of EMAS-registered organizations. The proposed model was particularly considered as the most effective in reaching the research aims, due to following reasons:

(1) It provides for both "external" and "internal" key themes, which organizations typically need to deploy when implementing digitalization. To the best of the authors' knowledge, existing literature lacks for integrated framework to digitalization and digital transformation;

(2) Exploring digitalization within the field of firms' environmental commitment means adopting a holistic perspective, according to which handling digitalization is an essential driver of environmental sustainability;

Figure 1.

Managerial actions for digital transformation initiatives

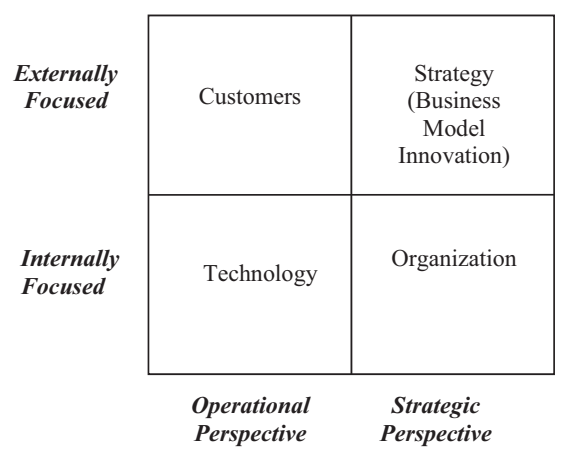

Source(s): Loonam et al.,(2018) 
(3) It was developed by reviewing ten successful digital transformations from the case literature to support scholars in understanding the actions required to implement digitalization.

\subsection{Data collection}

Environmental statements are published in national languages, thus international comparisons are hindered. Taking into account the authors' nationality, only the registered organizations from Italy and Poland were selected for investigation. As of November 2019, EMAS database holds records on more than 900 Italian companies registered and 30 Polish. Therefore, the research sample comprises all Polish organizations and a randomly selected equal sample of 30 Italian firms. Google's online random number generator was used, setting maximum number of population at 900 . The number draw was a company ordinal number in exported list of Italian companies. Due to small population of Polish registered companies, the whole sample was analyzed. Consequently, there were no restrictions in sample selection taking into consideration such items as its size, type of activity or others. The only assumption in the sample was the EMAS registration that confirms the high environmental performance.

In order to improve the coding process and to increase transparency of the research, each report was divided into four parts. The first one "Past (not-objectives)" contains a summary of the past activities described in Annex IV part B, section a) of environmental statements. The second part referring to "Past objectives" encompasses a description of the environmental objectives and targets and a description of the actions implemented provided in Annex IV part B, section (d) and (e) (related to the past). The third section named "Planned objectives" refers to a description of the environmental objectives and targets and a description of the actions planned contained in Annex IV part B, section (d) and (e) (related to the future). The last (fourth part) division of report's text named as "Other sections" appeals to all other sections in the environmental report mainly relating to present and future actions. In the coding process, all sections of the EMAS report were included and then analyzed. It means that all the EMAS reports were reorganized during the coding process in order to easily check the code categories. The last ones were identified in correspondence to each dimension. Referring to "digital initiative," code categorization followed the theoretical framework used for the study.

Following the proposed theoretical framework (Figure 1) and specificity of environmental reports (containing references to both past activities and future plans), 20 detailed code categories were identified. The code categories particularly belong to four following dimensions:

(1) Organization's details (registration number, EMAS registration date; number of employees, main business activity, Certified Quality Management System - ISO 14001, Certified Quality Management System - ISO 9001; Certified Quality Management System - BS OHSAS 18001 or ISO 45001; other management system);

(2) Part of EMAS statement ("past not-objectives," "past objectives," "planned objectives," "other sections").

(3) Digital initiatives (description of reference to digitalization; externally focused, internally focused, operational perspective, strategic perspective). As reported, digital initiatives followed the Loonam et al. (2018) framework.

(4) Time focus (past activities, future activities).

Table 1 contains list of codes employed in data charting.

\section{Digitalization in EMAS- registered organizations}

681 


\section{TQM 32,4}

\section{2}

\begin{tabular}{|c|c|c|}
\hline Dimensions & Code category & Code structure \\
\hline \multirow[t]{9}{*}{ Organization's details } & 1. Registration number & insert number \\
\hline & 2. EMAS registration date & insert year \\
\hline & 3. Numbers of employees & 1 - less than $50 ; 2$ - less than 250 ; \\
\hline & 4. Main business activity & 1 - production; 2 - services \\
\hline & $\begin{array}{l}\text { 5. Certified Quality Management } \\
\text { System - ISO } 14001\end{array}$ & $0-$ no; $1-$ yes \\
\hline & $\begin{array}{l}\text { 6. Certified Quality Management } \\
\text { System - ISO } 9001\end{array}$ & $0-$ no; $1-$ yes \\
\hline & $\begin{array}{l}\text { 7. Certified Quality Management System BS } \\
\text { OHSAS } 18001 \text { or ISO } 45001\end{array}$ & $0-$ no; $1-$ yes \\
\hline & 8. ISO 50001 & $0-$ no; 1 - yes \\
\hline & 9. Other management system & re-write \\
\hline \multirow{4}{*}{$\begin{array}{l}\text { Part of the EMAS } \\
\text { statement }\end{array}$} & 10. Past (not objectives) & 0 - no; 1 - yes \\
\hline & 11. Past objectives & 0 - no; 1 - yes \\
\hline & 12. Planned objectives & $0-$ no; $1-$ yes \\
\hline & 13. Other sections & 0 - no; 1 - yes \\
\hline \multirow[t]{5}{*}{ Digital initiatives } & 14. Description of references to digitalization & re-write \\
\hline & 15. Externally focused & $0-$ no; $1-$ yes \\
\hline & 16. Internally focused & $0-$ no; $1-$ yes \\
\hline & 17. Operational perspective & 0 - no; 1 - yes \\
\hline & 18. Strategic perspective & 0 - no; 1 - yes \\
\hline \multirow[t]{2}{*}{ Time focus } & 19. Past activities & $0-$ no; $1-$ yes \\
\hline & 20. Future activities & $0-$ no; $1-$ yes \\
\hline
\end{tabular}

Table 1. Coding matrix

Source(s): Authors' elaboration

1. Registration number

2. EMAS registration date

4. Main business activity

. Certified Quality Management

System - ISO 14001

Certified Quality Management

OHSAS 18001 or ISO 45001

8. ISO 50001

10. Past (not objectives)

11. Past objectives

14. Description of references to digitalization

15. Externally focused

Internally focused

19. Past activities

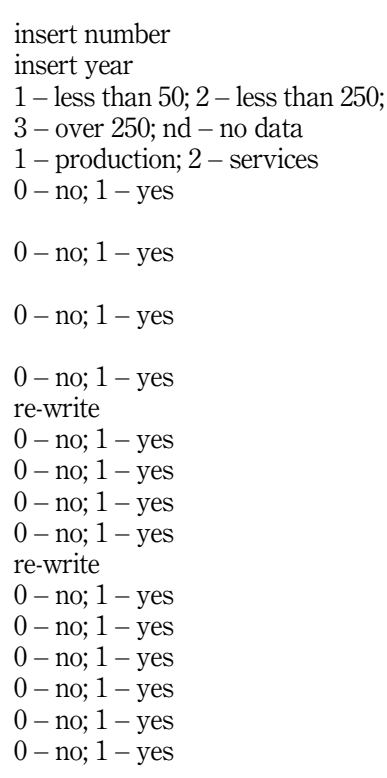

\subsection{Data analysis}

The extracted data were charted using Microsoft Excel forms. Next quantitative and qualitative content analysis was used to examine the data. Particularly, quantitative content analysis was managed in the manner in which it was originally conceived: to systematically identify, categorize and count the objective elements of the explored issue (Rourke and Anderson, 2004). This kind of analysis leaves little room for counter interpretation, and the results of descriptive studies are valuable (Riff et al., 2019), especially when they concern relatively new phenomena as the adoption of digital initiatives in high-performing environmental organizations.

Deductive categorization was theoretically based, as described in Section 3.2. After that, they were bridged to the text, as suggested by Mayring (2000). Category definitions, prototypical text passages and rules for distinguishing different categories were formulated with respect to theory and material, were completed step by step and were revised with the process of analysis (Mostyn, 1985).

Distinguished categories enabled the research team to describe digitalization activities in the selected sample. The results of the study are presented in the next section in accordance with the adopted theoretical framework.

\section{Results}

\subsection{Organization's details and objectives}

About 30 Italian and 30 Polish entities belong to the selected sample. Table 2 depicts it using code categories for "organization's details" divided into Italian and Polish organizations. The sample creates in terms of number of employment $27 \%$ small, $35 \%$ medium and $18 \%$ big organizations. In $20 \%$ of cases, there was no remark about employment number. The earliest 


\begin{tabular}{|c|c|c|c|c|c|}
\hline Dimension & Code category & IT & PL & Total & $\begin{array}{c}\text { Digitalization } \\
\text { in FMAS }\end{array}$ \\
\hline \multirow[t]{4}{*}{ Number of employees } & $<50$ & 14 & 2 & 16 & registered \\
\hline & $<250$ & 9 & 12 & 21 & \\
\hline & $>250$ & 6 & 5 & 11 & organizations \\
\hline & nd & 1 & 11 & 12 & \\
\hline \multirow[t]{2}{*}{ Main business activity } & Production & 11 & 15 & 26 & \\
\hline & Services & 19 & 15 & 34 & 683 \\
\hline \multirow{3}{*}{ EMAS registration date } & Earliest & 2002 & 2005 & - & \\
\hline & Latest & 2019 & 2016 & - & \\
\hline & Average time of registration & 7,1 & 6,0 & 6,6 & \\
\hline \multirow[t]{4}{*}{ Certified management system } & ISO 14001 & 27 & 19 & 46 & \\
\hline & ISO 9001 & 18 & 18 & 36 & \\
\hline & BS OHSAS 18001/ISO 45001 & 17 & 10 & 27 & \\
\hline & ISO 50001 & 4 & 1 & 5 & \\
\hline Source(s): Authors' elaboration & & & & & Organizations' details \\
\hline
\end{tabular}

EMAS certification happened in 2002 in Italian organizations as well as the recent ones in the last three years. In case of Polish organizations, the most intensive certification period was between 2011 and 2016. The average time of being registered is 6.5 years for the sample. The $57 \%$ of companies come from production sector, while $43 \%$ from service sector. $22 \%$ organizations do not have any certified management system. Other organizations provide certification according to ISO 14001 (40\%), ISO 9001 (32\%), OHSAS 18001/ISO 45001 (24\%) and ISO $50001(4 \%)$ management system requirements.

ICT reporting is more frequent in Polish organizations than in Italian ones. Moreover, highest number of mentions comes from environmental documentation prepared by mediumsize firms. More often digitalization is revealed in service organizations, both in past and in present objectives and tasks. Implementation of certified management systems according to such standards as: ISO 9001, ISO 14001, BS OHSAS 18001/ISO 45001 does not relate with digitalization. However, such relation is visible for those organizations that do not have ISO 50001 EMS standard requirements implemented. Table 3 presents details about the

\begin{tabular}{|c|c|c|c|c|c|c|}
\hline & $\begin{array}{l}\text { Code } \\
\text { category }\end{array}$ & $\begin{array}{l}\text { Past (not } \\
\text { objectives) }\end{array}$ & $\begin{array}{c}\text { Past } \\
\text { objectives }\end{array}$ & $\begin{array}{l}\text { Planned } \\
\text { objectives }\end{array}$ & $\begin{array}{l}\text { Other } \\
\text { sections }\end{array}$ & \\
\hline \multirow[t]{2}{*}{ Country } & IT & 6 & 7 & 3 & 5 & \\
\hline & PL & 13 & 7 & 5 & 18 & \\
\hline \multirow[t]{4}{*}{ Number of employees } & $<50$ & 4 & 2 & 2 & 4 & \\
\hline & $<250$ & 7 & 6 & 4 & 12 & \\
\hline & $>250$ & 3 & 5 & 1 & 1 & \\
\hline & nd & 5 & 1 & 1 & 6 & \\
\hline \multirow{2}{*}{$\begin{array}{l}\text { Main business } \\
\text { activity }\end{array}$} & Production & 9 & 5 & 2 & 7 & \\
\hline & Services & 10 & 9 & 6 & 16 & \\
\hline \multirow[t]{2}{*}{ ISO 9001} & No & 6 & 6 & 6 & 12 & \\
\hline & Yes & 13 & 8 & 2 & 11 & \\
\hline \multirow[t]{2}{*}{ ISO 14001} & No & 6 & 5 & 4 & 10 & \\
\hline & Yes & 13 & 9 & 4 & 13 & \\
\hline BS OHSAS 18001/ISO & No & 8 & 7 & 6 & 13 & \\
\hline 45001 & Yes & 11 & 7 & 2 & 10 & \\
\hline \multirow[t]{3}{*}{ ISO 50001} & No & 14 & 12 & 6 & 23 & Table 3. \\
\hline & Yes & 5 & 2 & 5 & 0 & Digitalization and \\
\hline & Total & 19 & 14 & 8 & 23 & $\begin{array}{l}\text { Digitalization and } \\
\text { organization's }\end{array}$ \\
\hline \multicolumn{2}{|c|}{ Source(s): Authors' elaboration } & & & & & characteristics \\
\hline
\end{tabular}


TQM

32,4

684

digitalization and "organization's details" as they were scanned in the "not objective" section, "past objectives," "planned objectives" and "other sections."

Totally, there were 59 mentions about digitalization; however, five entries have been classified both as being part and plan objectives (continuation). They were grouped on the basis of their nature. The following groups of technology usage were distinguished:

(1) remote access to organizations' utilities and machinery;

(2) releasing organization's data for external parties;

(3) 24/7 automated monitoring of environmental and production parameters;

(4) digitalized workflow, mainly for document management.

Table 4 contains examples for each digitalization type, as reported by the examined organizations.

With reference to past objectives and tasks, solutions aimed at improving electronic document flow within organization (seven entries) and publication information for customers and society (six entries) arise. Fewer entries were associated with automatization of organizational processes (two entries) and remote control of organizations utilities (one entry).

Digitalization in planned objectives and tasks continues the same tasks as presented earlier. Only one company listed digitalization within new objective. These new tasks referred to organization's website development for publishing news about undertaken environmental initiatives and use of tablets for the communication of good environmental practices.

The research team calculated the share of digitalized objectives in total environmental objectives where digitalization appeared. The value for past objectives is $15 \%$. The same number of mentions in planned objectives and tasks was identified.

\subsection{Digital initiatives}

Digitalization reported in environmental statements refers to both customers (22 entries) and internal purpose (37 entries). However, digitalized solutions have form of improving website or offering new digitalized content for society (18 of 22 entries). More diversified digitalization types aimed for improving organization's performance (see Table 4) were also observed. Nevertheless, majority of mentions about digitalization (24 out of 37 ) refers to electronic

\begin{tabular}{ll}
\hline Types & Examples \\
\hline Remote access to organizations' & (1) Remote control and steering of air-conditioning, lights, heating \\
utilities & (2) Product quality during production process is analyzed ongoing by \\
& \\
Making electronic information & (1) Publishing information for citizens living near the factory \\
public & (2) Electronic Platform of Public Administration Services (ePUAP) \\
& (3) Communicating the environmental reports on organization website \\
& (4) Publicly granting access to internal database \\
24/7 automated monitoring of & (5) Program ensuring public access to information in a public data \\
parameters & (1) 24 h weather forecast \\
Electronic document & (2) Online video transmission \\
management system & (1) Electronic document management system (system e-doc) \\
& (2) Sharing legal requirements among workers through Intranet \\
& (3) ERP system \\
& (4) Creation of a computerized database for historical data analysis
\end{tabular}

Table 4.

Digitalization types

Source(s): Authors' elaboration 
document management system. The rest of the examples of digitalization are business type dependent such as using online chromatograph or system for remote monitoring of water pump.

The distinguished types of digitalization appear in different settings. Electronic document management is internally oriented. The same applies to automated monitoring processes. Remote access to organization's utilities is described in environmental statements as innovation aimed at operational and internal context. Making electronic information public is externally oriented. Depending on the organization's decisions, it is sometimes considered as having a strategic purpose. This is the reason why it is also put in the "externally focused"/ "strategic perspective" quadrant.

Detailed research findings are showed in Figure 2.

All descriptions of digitalization in the EMAS statements were assigned according to theoretical framework. As a result, the number of references for Italian and Polish organizations are presented in Table 5. The most digitalization activities in total and for separate countries were assigned to the operational-internal dimensions. The smallest number of references concerned activities assigned to the strategic-external type of the framework.

\subsection{Time focus}

The 29\% (19) of organizations introduced some forms of digitalization in the first part of the environmental statement that was a summary of the organizations activities. Ten cases of modernization internally oriented at improving organizational performance and the same number at customers emerged. Half of them can be addressed to both internal purpose and social benefits. Five digital solutions relate to suppliers.

\begin{tabular}{|c|c|c|}
\cline { 2 - 3 } $\begin{array}{l}\text { Externally } \\
\text { Focused }\end{array}$ & $\begin{array}{l}\text { Making electronic information } \\
\text { public }\end{array}$ & $\begin{array}{l}\text { Making electronic information } \\
\text { public }\end{array}$ \\
\cline { 2 - 3 } $\begin{array}{l}\text { Internally } \\
\text { Focused }\end{array}$ & $-\begin{array}{l}\text { Document management } \\
\text { Remote access to organizations } \\
24 / 7 \text { automated monitoring of } \\
\text { parameters }\end{array}$ & n.a. \\
\cline { 2 - 3 } & \multicolumn{1}{|c|}{$\begin{array}{c}\text { Operational } \\
\text { Perspective }\end{array}$} \\
\multicolumn{1}{c|}{$\begin{array}{c}\text { Strategic } \\
\text { Perspective }\end{array}$} \\
\hline
\end{tabular}

Source(s): Authors' elaboration

\section{Digitalization in EMAS- registered organizations}

685

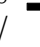


TQM

32,4

\section{6}

The next analyzed section of environmental statements was descriptions of past objectives and tasks to which document refers as the last one, prior to current attempts. About 13 mentions in 9 of $60(15 \%)$ were found in statements. The references to digitalization also appear in descriptions of planned objectives and tasks; however, in seven organizations only five out of 7 entries relate to internal organization while four to external communications and only one facilitates process monitoring.

About 23 mentions about digitalization in environmental statements were identified in the last part of the EMAS statements. About 14 of them deal with internal electronic document flow and nine with external digital communication; and among them, one also referred to automatization in production process.

When time of the digitalization is considered, there is a balance between past and present activities. Table 6 presents the data for the past and future digitalization activities within the adopted model. The total number of activities is higher than the total number of all identified mentions, due to the fact that some of the digitalization mentions in the last section of the environmental statements were coded as both past and future ones. As mentioned earlier, only in five cases, both past and planned objectives contained the same digitalization activities.

\section{Results discussion}

According to the research findings, almost half of environmental statements (43\%) contain reference to digitalization. Polish firms report the use of ICT more frequently than Italian one, with the highest number of references noted in medium-sized organizations.

As investments in digitalization are expensive and do not always bring the expected return on capital (Ruiz-Alba et al., 2019), this result only partially confirms the existing literature about the relationship between firms' propensity to digitalize and their dimension. Digitalization is largely seen as a powerful intervention into the core business of companies and associated with modernization efforts (Valenduc and Vendramin, 2017). Digital transformation increases the complexity and the uncertainty of actions, which a firm needs to undertake to fully grasp the benefits of technological advancements (Plekhanov and Netland, 2019). As firms want to integrate digital technologies into their business processes, operations and business models, new skills and competences are required, thus the level of digitalization is usually increasing with the firm's dimension growth (Laureti and Benedetti, 2019). In line with the mentioned, a study of micro-data from the Statistics Canada Survey of Advanced Technologies also confirms that large companies use advanced digital solutions more often in comparison to small and medium enterprises (Galindo-Rueda et al., 2019).

Sample selection procedure and firms industry could probably justify the results of this research, as EU Digital Transformation Scoreboard (2018) also confirms that European smaller firms belonging to agri-food and construction are more likely to adopt digital technologies than larger ones (Probst et al., 2018).

\begin{tabular}{lrrrrrr}
\hline & \multicolumn{2}{c}{ Operational } & \multicolumn{2}{c}{ Strategic } & \multicolumn{2}{c}{ Total } \\
& Past & Future & Past & Future & Past & Future \\
\hline External & 5 & 7 & 3 & 5 & 8 & 12 \\
Internal & 16 & 16 & 7 & 5 & 23 & 21 \\
Total & 21 & 23 & 10 & 10 & 31 & 33
\end{tabular}

Table 6.

digitalization activities
Past and future 
Looking at the "time focus," both production and service organizations report similar share of digitalization in the past. However, more often service providers mention digitalization in the present objectives.

In order to answer the first research question, references to the type of activities developed by EMAS-registered organizations were examined. Particularly, remote access to organizations' utilities and machinery, releasing organization's data for external parties, 24/7 automated monitoring of environmental and production parameters and digitalized workflow were detected as the main mentioned digital activities. It should be noted that none of them have radical nature: they are notable to disrupt business models and hardly revolutionize business as expected (Lakhani and Iansiti, 2014). Despite this, they are relevant when coming to EMAS, and to environmental management in general, as significant benefits of going digital are supported in the literature with reference to efficiency and effectiveness improvement (Parida et al., 2019).

The first group constitutes solutions enabling remote access to digitalization utilities. Such solutions represent the modernization due to cost-cutting by resource saving. The second group creates the facilitation of releasing the information for public use in Internet. It mainly refers to data regularly collected by organizations to which access was granted to paper version. This group can be associated with e-government initiatives in public administration (Plesner et al., 2018) and for private business as part of public relations (Just and Rasmussen, 2019). The third type of digitalization represents solutions granting ongoing $24 / 7$ possibilities to monitor the chosen parameters. The reason for using these solutions is the same as for the first group. The last group of digitalized solutions represents introduction of electronic data management. A mention for them is given by the transformation of paper work into electronic as typical example of organization's modernization driven by the need to deal with information overload and easy access to dispersed information within the organization.

In line with the adopted theoretical framework (Loonam et al., 2018), the most digitalization activities, in both total and individual countries, were assigned to the operational-internal dimensions. By contrast, the smallest number of references concerned activities assigned to the strategic-external perspective. It means that examined firms lack for any integrated approach to digitalization, contrasting with the mainstream about the topic (Loonam et al., 2018; Fanderl and Perrey, 2014).

Most of the reported digitalization activities are related to the - internally focused - simple actions such as document management, remote access to digitalization and automated monitoring of firms' parameters, suggesting the presence of a low level of digitalization of the examined EMAS-registered organizations, in line with what Evangelista et al. (2014) pointed out.

These findings show that organizations do not consider digitalization as something unexpected and significant to include in their environmental objectives and tasks. Therefore, it seems that digitalization does not shatter the organizational development in pursuing environmental impact. On the other hand, the lack of interest in usage of digitalization by organizations in the context of achieving EMAS goals may be a significant loss in terms of growth opportunities.

Since many authors emphasize the environmental benefits of digitalization (Bhutani and Paliwal, 2015; Antikainen et al., 2018; Seele and Lock, 2017), therefore new explorations are required to understand the linkage between the digitalization level and environmental performance of European firms, as digital transformation is indicated as one of the main purposes of the EU countries (Scholz et al., 2018).

With reference to the second research question, findings show that the intensity of digitalization does not change over the time in the EMAS-registered organization.

In general, the interest in digitalization does not increase in organizations registered in EMAS, even though the objectives relate essentially to environmental issues. 
TQM

32,4

688

Although modern systems and programs for production management allow to oversee processes in real time and to undertake immediate reaction to undesirable situations, they are not common in organizations with EMAS.

Going digital requires to pay more attention on information security. The ISO/IEC 27001 was created for this purpose, and this standard is the fourth most popular one according to ISO survey (ISO, 2018). However, none of organizations pointed out digitalization in their environmental statement, not reported the possession of the ISO/IEC 27001. There are two companies referring to ISO 2700, but both of them did not report digitalization. This research's findings indicate a lack of interest in information security. Missing systematic approach in this area suggests that EMAS organizations do not perceive this standard as crucial for their business. It also implies implementation of digitalization punctually within given business areas, having local impact.

According to ISO 14001, environmental objectives should take into account the organization's significant environmental aspects and associated compliance obligations (ISO, 2015). Therefore, the specific goals may be more general than the specific tasks related to their implementation. Supposing that digitalization is not itself an environmental goal, it can be stated that the objectives will not take it into account. Nevertheless, it is possible that the environmental goals could be achieved when planning the digitalization use. In this case, the low number of digitalization mentions in the environmental statements is explainable. On the other hand, the low number of digitalization mentions in the report could be associated with risks arising from digitalization in the context of sustainable development in the EMAS reports.

\section{Conclusions}

Considering the environmental benefits of digitalization, the research team aimed to verify if and how the companies involved in environmental protection are also digitalized.

Main research results may be pointed out in the following sentences:

(1) Polish EMAS firms use ICT more frequently than Italian ones.

(2) EMAS medium-sized firms are more digitalized than small and large firms.

(3) Both Polish and Italian EMAS-registered organizations characterize for a low - internally focused - level of digitalization.

(4) Both Polish and Italian EMAS-registered organizations lack any holistic perspective in managing digital initiatives.

In conclusion, both Polish and Italian organizations registered in EMAS do not express a strong propensity to use digital technologies in the pursuit of environmental goals, contrasting the assumptions about the benefits of digitalization for sustainable development, actually available in the literature.

According to the findings, well-established types of digitalization are not a radical foundation for current business models. On the basis of the analyzed companies, the main groups of technology applications were determined, that is, remote access to the organization's tools and machines, sharing organization data with external entities, 24/7 automated monitoring of environmental and production parameters and digital office workflow. Mainly because only environmental statements that are part of the EMAS certification were examined by the research team, it is worth checking whether research results will also be confirmed by companies using the second widely recognized EMS: ISO 14001.

The analysis showed that organizations registered in EMAS do not express a strong tendency to introduce ICT in pursuit of environmental goals, which is contrary to the 
assumptions about the benefits of digitalization in the EMS commonly recognized within the literature. Due to the fact that the research covered various organizations in terms of sector and size, they state that the transformation of the business model using computer technology into green business is currently limited. Problems with implementing digitalization in the environmental strategies of the organizations surveyed may be caused by a lack of technological and technical knowledge about digitalization. Although modern production management systems and programs allow to monitor processes in real time and take immediate response to undesirable situations, it has been observed that interest in digitalization is not growing for an EMAS-registered organization.

The main limitation of the analysis is that it covers only the Polish and Italian companies. According to the Digital Economy and Society 2017 Index published by EU (European Commission, 2017), both Poland and Italy are ranked at the end of the list - respectively 24 and 26 places out of 29 . So the digitalization progress of studied countries may affect the obtained results in this study.

According to the aforementioned, enlarging the research network, in order to improve the sample, is strongly recommended.

Despite its limits, this paper has some theoretical and practical implications.

From a theoretical perspective, this research enriches the current knowledge about digitalization for environmental sustainability, examining two dynamically developing areas for the first time. To the best of the authors' knowledge, this is the first study exploring the level of digitalization in EMAS-registered organizations.

Moreover, it opens for future research directions about the linkage between digitalization and firm's environmental performance. Particularly, the following questions need to be answered:

(1) Why do EMAS-registered organizations show low level of digitalization?

(2) Under which circumstances does digitalization not support firms' environmental goals and performance?

(3) What is the perception that EMAS-registered organizations have about the environmental benefits of digitalization?

(4) How does firms' industry affect digitalization in high-environmental performing organizations?

(5) Do contextual factors (e.g. local culture, resource availability, suppliers' level of digitalization, customers' requests) affect EMAS-registered organizations' propensity to digitalize their activities?

As this study investigated only environmental statements being part of EMAS certification, it would be also interesting, for a future research, to check if results are also confirmed in companies using the second commonly recognized EMS: ISO 14001.

From a practical point of view, this paper offers to the practitioners the chance to catch new opportunities within the field of environmental sustainability by the employment of more integrated approach to digitalization.

\section{References}

Aksin-Sivrikaya, S. and Bhattacharya, C.B. (2017), "Where digitalization meets sustainability: opportunities and challenges", in Osburg, T. and Lohrmann, C. (Eds), Sustainability in a Digital World. CSR, Sustainability, Ethics \& Governance, Springer, Cham.

Al-Samawi, Y. (2019), "Digital firm: requirements, recommendations, and evaluation the success in digitization", I.J. Information Technology and Computer Science, Vol. 1, pp. 39-49.

\section{Digitalization in EMAS- registered organizations}

689 
TQM 32,4

Antikainen, M., Uusitalo, T. and Kivikytö-Reponen, P. (2018), "Digitalisation as an enabler of circular economy", Procedia CIRP, Vol. 73, pp. 45-49, doi: 10.1016/j.procir.2018.04.027.

Baccarani, C. and Cassia, F. (2017), "Evaluating the outcomes of service ecosystems: the interplay between ecosystem well-being and customer well-being", The TQM Journal, Vol. 29 No. 6, pp. 834-846, doi: 10.1108/TQM-04-2017-0039.

Baines, T., Bigdeli, A.Z., Bustinza, O.F., Shi, V.G., Baldwin, J. and Ridgway, K. (2017), "Servitization: revisiting the state-of-the-art and research priorities", International Journal of Operations \& Production Management, Vol. 37 No. 2, pp. 256-278.

Barbier, E.B. (1987), "The concept of sustainable economic development", Environmental Conservation, Vol. 14, pp. 101-110.

Barile, S., Ciasullo, M.V., Troisi, O. and Sarno, D. (2017), "The role of technology and institutions in tourism service ecosystems: findings from a case study", The TQM Journal, Vol. 29 No. 6, pp. 811-833, doi: 10.1108/TQM-06-2017-0068.

Beier, G., Niehoff, S., Ziems, T. and Xue, B. (2017), "Sustainability aspects of a digitalized industry-A comparative study from China and Germany", International Journal of Precision Engineering and Manufacturing-Green Technology, Vol. 4 No. 2, pp. 227-234.

Berman, S.J. and Bell, R. (2011), Digital Transformation: Creating New Business Models where Digital Meets Physical, IBM Institute for Business Value, Somers, NY, pp. 1-17.

Berry, M. and Rondinelli, D. (1998), "Proactive corporate management: environmental new industrial revolution", Academy of Management Perspectives, Vol. 12 No. 2, pp. 38-50.

Bhutani, S. and Paliwal, Y. (2015), "Digitalization: a step towards sustainable development", OIDA International Journal of Sustainable Development, Vol. 8 No. 12, pp. 11-24.

Bieser, J.C.T. and Hilty, L.M. (2018), "An approach to assess indirect environmental effects of digitalization based on a time-use perspective" in Bungartz, H.J., Kranzlmüller, D., Weinberg, V., Weismüller, J. and Wohlgemuth, V. (Eds), Advances and New Trends in Environmental Informatics, Progress in IS, Springer, Cham, pp. 67-78.

Bressanelli, G., Adrodegari, F., Perona, M. and Saccani, N. (2018), "Exploring how usage-focused business models enable circular economy through digital technologies", Sustainability, Vol. 10 No. 3, p. 639.

Calvino, F., Criscuolo, C., Marcolin, L. and Squicciarini, M., (2018), "A taxonomy of digital intensive sectors”, OECD Science, Technology and Industry Working Papers No. 2018/14, Paris, doi: 10. 1787/f404736a-en.

Canestrino, R., Bonfanti, A., Magliocca, P. and Oliaee, L. (2016), "Networks for Social Innovation: devoting 'learning spaces' to social aims", IFKAD Conference, Dresden.

Capozzi, M., Chan, V., de Jong, M. and Roth, E.A. (2014), "Meeting the innovation imperative: how large defenders can go on the attack", McKinsey on Marketing \& Sales, available at: Mckinseyonmarketingandsales.com.

Catlin, T., Scanlan, J. and Willmott, P. (2015), "Raising your digital quotient", McKinsey Quarterly, pp. 1-14.

Cenamor, J., Sjödin, D.R. and Parida, V. (2017), "Adopting a platform approach in servitization: leveraging the value of digitalization", International Journal of Production Economics, Vol. 192, pp. 54-65.

Chiarini, A. (2013), "Designing an environmental sustainable supply chain through ISO 14001 standard”, Management of Environmental Quality, Vol. 24 No. 1, pp. 16-33, doi: 10.1108/ 14777831311291113.

Ciocoiu, C. (2011), "Integrating digital economy and green economy: opportunities for sustainable development", Theoretical and Empirical Researches in Urban Management, Vol. 6 No. 1, pp. 33-43.

Coupette, C. (2015), "Legal Tech will fundamentally change legal research - interview with Dr. Hanjo Hamann [online]”, Legal Tech Blog, available at: http://legal-tech-blog.de/legal-tech-will-changelegal-research (accessed 14 September 2015). 
Daddi, T., Testa, F., Iraldo, F. and Frey, M. (2014), "Removing and simplifying administrative costs and burdens for EMAS and ISO 14001 certified organizations: evidences from Italy", Environmental Engineering \& Management Journal, Vol. 13 No. 3, pp. 689-698.

Desmet, D., Duncan, E., Scanlan, J. and Singer, M. (2015), Six Building Blocks for Creating a HighPerforming Digital Enterprise, McKinsey \& Company, available at: https:/www.mckinsey.com/ business-functions/organization/our-insights/six-building-blocks-for-creating-a-high-performingdigital-enterprise, https:/www.mckinsey.com/business-functions/organization/our-insights/sixbuilding-blocks-for-creating-a-high-performing-digital-enterprise.

EU (2009), "Regulation (EC) No 1221/2009 of the European Parliament and of the Council of 25 November 2009 on the voluntary participation by organisations in a Community ecomanagement and audit scheme (EMAS), repealing Regulation (EC) No 761/2001 and Commission Decisions 2001/681/EC and 2006/193/EC", available at: https:/eur-lex.europa.eu/ legal-content/EN/TXT/?qid=1589194854431\&uri=CELEX:02009R1221-20190109.

European Commission (2017), “Commission staff working document”, Europe's Digital Progress Report 2017, Brussels.

European Commission (2019), "Eco-management and audit scheme - register", WWW Document, available at: http://ec.europa.eu/environment/emas/register/search/search.do.

Evangelista, R., Guerrieri, P. and Meliciani, V. (2014), "The economic impact of digital technologies in Europe", Economics of Innovation and New Technology, Vol. 23 No. 8, pp. 802-824.

Fanderl, H. and Perrey, J. (2014), "Best of both worlds: customer experience for more revenues and lower costs", McKinsey on Marketing \& Sales, available at: Mckinseyonmarketingandsales.com.

Fokina, O.V., Fufacheva, L.A., Sozinova, A.A., Sysolyatin, A.V. and Bulychev, L.L. (2018), "Information and communication technologies as a new vector of development of modern global economy”, Revista Espacios, Vol. 39 No. 28, p. 5.

Forge, S., Blackman, C., Bohlin, E. and Cave, M. (2009), A Green Knowledge Society. An ICT Policy Agenda to 2015 for Europes Future Knowledge Society, A Report for the Ministry of Enterprise, Energy and Communication, Government Offices of Sweden.

Freimann, J. and Walther, M. (2002), "The impacts of corporate environmental management systems: a comparison of EMAS and ISO 14001", in Greener Management International, Greenleaf Publishing, Sheffield.

Galindo-Rueda, F., Ouellet, S. and Verger, F. (2019), "Exploring patterns of advanced technology and business practice use and the link with innovation: an empirical case study based on Statistics Canada's Survey of Advanced Technologies", OECD Science, Technology and Industry Working Papers, OECD Publishing, Paris, doi: 10.1787/18151965.

GeSI (2015), SMARTer 2030, ICT Solutions for 21st Century Challenges, Global e-Sustainability Initiative, Brüssels.

Gimpel, H. and Schmied, F. (2019), "Risks and side effects of digitalization: a multi-level taxonomy of the adverse effects of using digital technologies and media", in Proceedings of the 27th European Conference on Information Systems (ECIS), Stockholm \& Uppsala, ISBN 978-1-7336325-0-8, available at: https:/aisel.aisnet.org/cgi/viewcontent.cgi?article=1144\&context=ecis2019_rp.

Gimpel, H., Hosseini, S., Huber, R., Probst, L., Röglinger, M. and Faisst, U. (2018), "Structuring digital transformation: a framework of action fields and its application at ZEISS", Journal of Information Technology Theory and Application, Vol. 19 No. 1, pp. 31-54.

Gorissen, L., Vrancken, K. and Manshoven, S. (2016), "Transition thinking and business model innovation-Towards a transformative business model and new role for the reuse centers of Limburg, Belgium”, Sustainability, Vol. 8 No. 2, p. 112.

Grubic, T. and Jennions, I. (2018), "Remote monitoring technology and servitised strategies-factors characterising the organisational application”, International Journal of Production Research, Vol. 56 No. 6, pp. 2133-2149.

Hasselblatt, M., Huikkola, T., Kohtamäki, M. and Nickell, D. (2018), "Modeling manufacturer's capabilities for the Internet of Things", Journal of Business \& Industrial Marketing, Vol. 33, pp. 822-836.
Digitalization in EMASregistered organizations 
TQM 32,4

692

Hedberg, A., Šipka, S. and Bjerkem, J. (2019), "Creating a digital roadmap for a circular economy", Sustainable Prosperity for Europe Programme, European Policy Centre, available at: https:// wms.flexious.be/editor/plugins/imagemanager/content/2140/PDF/2019/pub_difital_roadmap_ for_circular_economy.pdf.

Heiskala, M., Jokinen, J.P. and Tinnilä, M. (2016), "Crowdsensing-based transportation services. An analysis from business model and sustainability viewpoints", Research in Transportation Business \& Management, Vol. 18, pp. 38-48.

Hess, T., Matt, C., Benlian, A. and Wiesböck, F. (2016), "Options for formulating a digital transformation strategy”, MIS Q. Executive, Vol. 15 No. 2, pp. 112-139.

Hillary, R. (1999), Valuation of Study Reports on the Barriers, Opportunities and Drivers for Small and Medium Sized Enterprises in the Adoption of EMSs, Department of Trade and Industry, London.

Hilty, L. and Bieser, J. (2017), Opportunities and Risks of Digitalization for Climate Protection in Switzerland, University of Zurich, Zurich.

Iraldo, F., Testa, F. and Frey, M. (2009), "Is an environmental management system able to influence environmental and competitive performance? The case of the eco-management and audit scheme (EMAS) in the European Union”, Journal of Cleaner Production, Vol. 17 No. 16, pp. 1444-1452.

i-SCOOP (2018), "Digitization, digitalization and digital transformation: the differences", available at: https://www.i-scoop.eu/digitization-digitalization-digital-transformation-disruption/.

ISO (2015), ISO 14001:2015 Environmental Management Systems. Requirements with Guidance for Use, ISO, Geneva.

ISO (2018), The ISO Survey of Certifications - 2018, International Organization for Standardization, Geneva.

Jabbour, C., de Freitas, T., Soubihia, D., Gunasekaran, A. and Jabbour, A. (2015), "Green and competitive: empirical evidence from ISO 9001 certified Brazilian companies", The TQM Journal, Vol. 27 No. 1, pp. 22-41, doi: 10.1108/TQM-01-2013-0013.

Just, S.N. and Rasmussen, R.K. (2019), "When data is the issue: Re-conceptualizing public relations for the platform economy”, Advances in Public Relations and Communication Management, Vol. 4, pp. 25-38, doi: 10.1108/S2398-391420190000004003.

Kafel, P. and Casadesus, M. (2016), "The order and level of management standards implementation: changes during the time", The TQM Journal, Vol. 28 No. 4, pp. 636-647.

Kagermann, H. (2015), "Change through digitization - value creation in the age of industry 4.0", in Albach, H., Meffert, H., Pinkwart, A. and Reichwald, R. (Eds), Management of Permanent Change, Springer Gabler, Wiesbaden, pp. 23-45.

Kaufmann, T. (2015), Geschäftsmodelle in Industrie 4.0 und dem Internet der Dinge, Der Weg vom Anspruch in die Wirklichkeit, Springer Vieweg, Wiesbaden.

Keen, P. and Williams, R. (2013), "Value architectures for digital business: beyond the business model”, MIS Quarterly, Vol. 37 No. 2, pp. 643-647.

Klute-Wenig, S. and Refflinghaus, R. (2015), "Integrating sustainability aspects into an integrated management system”, The TQM Journal, Vol. 27 No. 3, pp. 303-315, doi: 10.1108/TQM-122013-0128.

Kobus, J., Westner, M., Strahringer, S. and Strode, D. (2018), "Enabling digitization by implementing Lean IT: lessons learned”, The TQM Journal, Vol. 30 No. 6, pp. 764-778, doi: 10.1108/TQM-022018-0026.

Kyriakidou, V., Michalakelis, C. and Sphicopoulos, T. (2011), "Digital divide gap convergence in Europe”, Technology in Society, Vol. 33 Nos 3-4, pp. 265-270, doi: 10.1016/j.techsoc.2011.09.001.

Lakhani, K.R. and Iansiti, M. (2014), "Digital ubiquity: how connections, sensors, and data are revolutionizing business", Harvard Business Review, Vol. 92 No. 11, pp. 90-99.

Laudon, K.C. and Laudon, J.P. (2012), Management Information Systems - Managing the Digital Firm, 13th ed., Pearson. 
Laureti, T. and Benedetti, I. (2019), "Indagine sul grado di digitalizzazione delle imprese della Tuscia", Report, Dipartimento di Economia, Ingegneria, Società e Impresa- Università della Tuscia.

Linz, C., Muller-Stewens, G. and Zimmermann, A. (2017), Radical Business Model Transformation: Gaining the Competitive Edge in a Disruptive World, Kogan Page Publishers.

Loebbecke, C. and Picot, A. (2015), "Reflections on societal and business model transformation arising from digitization and big data analytics: a research agenda", The Journal of Strategic Information Systems, Vol. 24 No. 3, pp. 149-157.

Loonam, J., Eaves, S., Kumar, V. and Parry, G. (2018), "Towards digital transformation: lessons learned from traditional organizations", Strategic Change, Vol. 27 No. 2, pp. 101-109.

Marrucci, L., Daddi, T. and Iraldo, F. (2019), "The integration of circular economy with sustainable consumption and production tools: systematic review and future research agenda", Journal of Cleaner Production, Vol. 240, p. 118268.

Matt, C., Hess, T. and Benlian, A. (2015), "Digital transformation strategies", Business \& Information Systems Engineering, Vol. 57 No. 5, pp. 339-343.

Mayring, P. (2000), "Qualitative content analysis”, Forum: Qualitative Social Research, Vol. 1 No. 2(20), available at: http://nbn-resolving.de/urn:nbn:de:0114-fqs0002204.

Morrow, D. and Rondinelli, D. (2002), "Adopting corporate environmental management systems: motivations and results of ISO 14001 and EMAS certification", European Management Journal, Vol. 20 No. 2, pp. 159-171.

Mostyn, B. (1985), "The content analysis of qualitative research data: a dynamic approach", in Brenner, M., Brown, J. and Cauter, D. (Eds), The Research Interview, Academic Press, London, pp. $115-145$.

Neugebauer, F. (2012), "EMAS and ISO 14001 in the German industry. Complements or substitutes?", Journal of Cleaner Production, Vol. 37, pp. 249-256.

Neumeier, A., Wolf, T. and Oesterle, S. (2017), "The manifold fruits of digitalization-determining the literal value behind", 13th International Conference on Wirtschaftsinformatik, 12-15 February 2017, St. Gallen, Switzerland.

Oghazi, P. and Mostaghel, R. (2018), "Circular business model challenges and lessons learned. An Industrial Perspective”, Sustainability, Vol. 10 No. 3, p. 739.

Pamlin, D. and Szomolányi, K. (2006), Saving the Climate @ the Speed of light, First Roadmap for Reduced CO2 Emissions in the EU and beyond, European Telecommunications Network Operators' Association, WWF.

Pane-Haden, S.S., Oyler, J.D. and Humphreys, J.H. (2009), "Historical, practical and theoretical perspective on green management: an exploratory analysis", Management Decision, Vol. 47 No. 7, pp. 1041-1055.

Parida, V., Sjödin, D.R., Wincent, J. and Kohtamäki, M. (2014), "Mastering the transition to productservice provision: insights into business models, learning activities, and capabilities", ResearchTechnology Management, Vol. 57 No. 3, pp. 44-52.

Parida, V., Sjödin, D. and Reim, W. (2019), "Reviewing literature on digitalization, business model innovation, and sustainable industry: past achievements and future promises", Sustainability, Vol. 11, p. 391, doi: 10.3390/su11020391.

Peter, M.K., Kraft, C. and Lindeque, J. (2020), "Strategic action fields of digital transformation”, Journal of Strategy and Management, Vol. 13 No. 1, pp. 160-180.

Plekhanov, D. and Netland, T.H. (2019), "Digitalisation stages in firms: towards a framework", 26th EurOMA Conference 2019, Helsinki.

Plesner, U., Justesen, L. and Glerup, C. (2018), "The transformation of work in digitized public sector organizations", Journal of Organizational Change Management, Vol. 31 No. 5, pp. 1176-1190.

Porter, M.E. and Heppelmann, J.E. (2015), "How smart, connected products are transforming companies", Harvard Business Review, Vol. 93 No. 10, pp. 96-114.

\section{Digitalization in EMAS- registered organizations}


TQM 32,4

Probst, L., Röglinger, M. and Faisst, U. (2018), "Structuring digital transformation: a framework of action fields and its application at ZEISS", Journal Information Technology Theory and Application, Vol. 19, pp. 31-54.

Preziosi, M., Merli, R. and D'Amico, M. (2016), "Why companies do not renew their EMAS registration? An exploratory research”, Sustainability, Vol. 8 No. 2, p. 191.

Rachinger, M., Rauter, R., Müller, C., Vorraber, W. and Schirgi, E. (2019), "Digitalization and its influence on business model innovation", Journal of Manufacturing Technology Management, Vol. 30 No. 8, pp. 1143-1160, doi: 10.1108/JMTM-01-2018-0020.

Riff, D., Lacy, S., Fico, F. and Watson, B. (2019), Analyzing Media Messages: Using Quantitative Content Analysis in Research, Routledge.

Ringenson, T., Höjer, M., Kramers, A. and Viggedal, A. (2018), "Digitalization and environmental aims in municipalities", Sustainability, Vol. 10 No. 4, p. 1278.

Rohn, H., Pastewski, N., Lettenmeier, M., Wiesen, K. and Bienge, K. (2014), "Resource efficiency potential of selected technologies, products and strategies", The Science of the Total Environment, Vol. 473, pp. 32-35.

Rourke, L. and Anderson, T. (2004), "Validity in quantitative content analysis", Educational Technology Research and Development, Vol. 52 No. 1, pp. 5-18.

Ruiz-Alba, J.L., Guesalaga, R., Ayestarán, R. and Morales Mediano, J. (2019), "Interfunctional coordination: the role of digitalization”, Journal of Business \& Industrial Marketing, doi: 10.1108/JBIM-03-2019-0129.

Scholz, R.W., Bartelsman, E.J., Diefenbach, S., Franke, L., Grunwald, A., Helbing, D., Hill, R., Hilty, L., Höjer, M., Klauser, S., Montag, C., Parycek, P., Prote, J.P., Renn, O., Reichel, A., Schuh, G., Steiner, G. and Pereira, G.V. (2018), "Unintended side effects of the digital transition: European scientists' messages from a proposition-based expert round table", Sustainability, Vol. 10 No. 6, doi: 10.3390/su10062001.

Seele, P. and Lock, I. (2017), "The game-changing potential of digitalization for sustainability: possibilities, perils, and pathways", Sustainability Science, Vol. 12 No. 2, pp. 183-185, doi: 10.1007/s11625-017-0426-4.

Sjödin, D.R., Parida, V., Leksell, M. and Petrovic, A. (2018), "Smart Factory Implementation and Process Innovation: a preliminary maturity model for leveraging digitalization in manufacturing. Moving to smart factories presents specific challenges that can be addressed through a structured approach focused on people, processes, and technologies", ResearchTechnology Management, Vol. 61 No. 5, pp. 22-31.

Steurer, R., Langer, M.E., Konrad, A. and Martinuzzi, A. (2005), "Corporations, stakeholders and sustainable development i: a theoretical exploration of business-society relations", Journal of Business Ethics, Vol. 61 No. 3, pp. 263-281.

Testa, F., Rizzi, F., Daddi, T., Gusmerotti, N.M., Frey, M. and Iraldo, F. (2014), "EMAS and ISO 14001: the differences in effectively improving environmental performance", Journal of Cleaner Production, Vol. 68, pp. 165-173.

Unruh, G. and Kiron, D. (2017), Digital Transformation on Purpose, MIT Sloan Management Review.

Valenduc, G. and Vendramin, P. (2017), "Digitalisation, between disruption and evolution”, Transfer: European Review of Labour and Research, Vol. 23, pp. 121-134, doi: 10.1177/1024258917701379.

Van der Leeuw, S. (2018), "Closing remarks: novel approaches to complex societal change and sustainability”, Sustainability Science, Vol. 13 No. 6, pp. 1589-1596.

Verina, N. and Titko, J. (2019), "Digital transformation: conceptual framework", International Scientific Conference "Contemporary Issues in Business, Management and Economics Engineering", Vilnius.

Wade, M. (2015), “A conceptual framework for digital business transformation”, IMD and CISCO, available at: https://www.imd.org/uupload/IMD.WebSite/DBT/Digital\%20Business \%20Transformation \%20Framework.pdf (accessed 20 October 2017). 
Warner, K.S.R. and Wäger, M. (2019), "Building dynamic capabilities for digital transformation: an ongoing process of strategic renewal”, Long Range Planning, Vol. 52 No. 3, pp. 326-349, doi: 10.1016/j.lrp.2018.12.001.

Webb, M. (2008), SMART 2020: Enabling the Low Carbon Economy in the Information Age, a Report by the Climate Group on Behalf of the Global eSustainability Initiative (GeSI), Creative Commons.

Digitalization in EMASregistered organizations

Westerman, G., Calméjane, C., Bonnet, D., Ferraris, P. and McAfee, A. (2011), Digital Transformation: A Road-Map for Billion-Dollar Organizations, MIT Center for Digital Business and Capgemini Consulting, Cambridge, MA and Paris.

Westerman, G., Bonnet, D. and McAfee, A. (2014), Leading Digital: Turning Technology into Business Transformation, Harvard Business Press.

\section{Corresponding author}

Piotr Kafel can be contacted at: kafelp@uek.krakow.pl

For instructions on how to order reprints of this article, please visit our website:

www.emeraldgrouppublishing.com/licensing/reprints.htm

Or contact us for further details: permissions@emeraldinsight.com 